\title{
A Reduction in the Use of Volunteered Descriptors of Air Hunger Is Associated With Increased Walking Distance in People With COPD
}

\author{
Marie T Williams PhD, John Petkov MSc, Timothy S Olds PhD, \\ Paul Cafarella, and Peter Frith MBBS FRACP
}

\begin{abstract}
BACKGROUND: This study investigated whether descriptors of breathlessness differed after participation in an 8 week pulmonary rehabilitation program and whether changes in sensory quality would be reflected in responsiveness to pulmonary rehabilitation. METHODS: People with COPD provided descriptors for their sensation of breathlessness before and after an 8 week pulmonary rehabilitation program. Primary outcomes for responsiveness to pulmonary rehabilitation were the 6 minute walk distance (6MWD) and the St George Respiratory questionnaire. Significant proportional shifts for sensory categories after rehabilitation were identified using the McNemar test. Random effects mixed modeling was used to determine significance of differences for primary outcomes between subjects modifying or not modifying descriptors of breathlessness. RESULTS: Of the 107 people referred to the pulmonary rehabilitation program, 94 met the spirometric criteria for COPD, with 58 having data for pre and post assessments (36 males, $71 \pm 9$ years old, percent of predicted $\mathrm{FEV}_{1} 58 \pm \mathbf{2 4 \%}$ ). A significant proportion of subjects reduced descriptors of air hunger $(P=.03$, odds ratio $0.31,95 \% \mathrm{CI} 0.09-0.89)$ and depressed, regret, helpless $(P=.04$, odds ratio 0.36 , 95\% CI 0.10-1.05) following rehabilitation. Subjects reducing their use of descriptors of air hunger had greater improvements in the 6MWD after rehabilitation $(P=.006$, mean increase $46 \mathrm{~m})$. CONCLUSIONS: The sensory quality of breathlessness was modified for approximately one third of subjects after pulmonary rehabilitation, with significant improvements in the 6MWD for subjects who reduced their use of descriptors of air hunger. Key words: dyspnea; breathlessness; pulmonary rehabilitation; COPD. [Respir Care 2012;57(9):1431-1441. ( 2012 Daedalus Enterprises]
\end{abstract}

\section{Introduction}

For people with COPD, research evidence supports participation in comprehensive pulmonary rehabilitation pro-

Dr Williams is affiliated with the School of Health Sciences; Mr Petkov is affiliated with the Applied Statistics Unit; and Dr Olds is affiliated with the Health and Use of Time Group, Sansom Institute for Health Research, University of South Australia, Adelaide, South Australia, Australia. Mr Cafarella is affiliated with the Department of Respiratory Medicine; and Dr Frith is affiliated with Respiratory Services, Southern Adelaide Health Service, Repatriation General Hospital, Adelaide, South Australia, Australia.

This work was partly supported by a grant from the Physiotherapy Research Foundation, Cardiorespiratory Physiotherapy Clinical Group of the Australian Physiotherapy Association.

Dr Williams presented a version of this paper at the Physiotherapy Research Foundation Oration 10th Biennial Cardiorespiratory Physiother- grams (CPRP) to reduce the impact of dyspnea on impairment and quality of life. ${ }^{1,2}$ Exercise of sufficient duration and intensity is associated with reduction in skeletal muscle dysfunction, may enhance mechanical efficiency of physical activities, and may reduce or delay the onset of

apy Australia Conference, held October 4-9, 2008, in Cairns, Queensland, Australia.

Dr Frith has disclosed relationships with AltanaPharma, AstraZeneca, Boehringer Ingelheim, Bayer Pharmaceuticals, GlaxoSmithKline, Nycomed, and Pfizer. The other authors have disclosed no conflicts of interest.

Correspondence: Marie T Williams PhD, School of Health Sciences, University of South Australia, City East Campus, North Terrace 5000, Adelaide, South Australia, Australia. E-mail: marie.williams@unisa. edu.au.

DOI: $10.4187 /$ respcare. 01513 
dynamic hyperinflation during exercise and reduce sensitivity to dyspnea. ${ }^{1-7}$ While participation in CPRP has been shown to reduce the intensity of dyspnea and impact of dyspnea on health related quality of life, ${ }^{2}$ whether participation in CPRP moderates the qualitative sensation of dyspnea is less clear.

The sensation of dyspnea is currently thought to have 3 domains: intensity, sensory quality (descriptors), and unpleasantness. ${ }^{8,9}$ From an evolutionary perspective, sensation drives behavior. Lansing et al recently proposed a model for the perceptual processes underpinning the sensation of breathlessness. Afferent input is initially evaluated for intensity and sensory quality, followed by an assessment of unpleasantness, which culminates in immediate and longer term emotional (fear, frustration, anxiety) and behavioral consequences (immediate cessation of activity or lifestyle changes). ${ }^{9}$

The intensity and unpleasantness of the sensation of dyspnea are usually assessed with scales such as a visual analog scale or a perceived rate of exertion..$^{10,11}$ The sensory quality of the sensation is assessed by the language (descriptive words or phrases) used to describe the sensation. Descriptors can include both emotional and physical terms. Emotive descriptors (eg, frightening, anxiety, depression) are likely to reflect the degree of unpleasantness and threat posed to survival by activating the association cortex and limbic system. Physical terms (eg, work effort, unsatisfied inspiration/air hunger, tightness) $)^{8,12}$ are thought to involve the somatosensory cortex and association cortex (among other neural structures) monitoring efferent information such as the magnitude of efferent motor output via central corollary discharge (sense of work/effort) or discrepancies between central respiratory motor output and the mechanical/muscular response of the respiratory system (sense of unsatisfied inspiration/air hunger). ${ }^{7}$ The sensation of air hunger has the potential to evoke an affective (fear) response and is associated with greater unpleasantness than the induced sense of respiratory work/effort. ${ }^{13}$

There are a variety of instruments with which to assess the sensory quality of breathlessness (descriptors), including instruments that invite respondents to volunteer descriptors, ${ }^{14}$ select from a series of descriptors statements, ${ }^{15,16}$ or rate the intensity of descriptor statements. ${ }^{17}$ To date, instruments that assess the sensory quality of breathlessness have generally been used to compare the experience of breathlessness between chronic conditions where dyspnea is a common feature or explore differing physiological mechanisms of breathlessness, rather than to assess intervention efficacy or disease progression. Two studies have explored the impact of pulmonary rehabilitation on the sensory quality of breathlessness. Von Leupoldt et al ${ }^{18}$ invited participants to rate the intensity of 22 statements describing differing sensory qualities, and reported a reduction in the mean intensity of sensory qual-

\section{QUICK LOOK}

\section{Current knowledge}

Participation in pulmonary rehabilitation has been shown to reduce the intensity of dyspnea and impact of dyspnea on health related quality of life. However, the effect on the qualitative sensation of dyspnea is not well defined.

\section{What this paper contributes to our knowledge}

The sensory quality of breathlessness was modified for approximately one third of subjects after pulmonary rehabilitation. Sensations of dyspnea or air hunger may prove useful for monitoring patient response to rehabilitation.

ities following participation in a 15 day pulmonary rehabilitation program. Bianchi et al ${ }^{19}$ invited participants to select up to 3 out of a potential 15 descriptors statements, and while the frequency of descriptors selection did not differ significantly before or after a 4 week pulmonary rehabilitation program, a third of subjects modified their choice of breathlessness descriptors. While there is debate concerning the optimal frequency and duration of exercise training within CPRP, a number of guidelines recommend that exercise training for people with COPD participating in CPRP should occur 3 times a week for a duration of at least $6-12$ weeks. ${ }^{1,3,4,5,20}$ These 2 studies ${ }^{18,19}$ indicate that the intensity and, possibly, the type of breathlessness sensation can be modified by participation in CPRP of shorter duration.

One of the issues with requesting participants to rate or select descriptors (endorsement approach) is that, in the absence of an exhaustive list, subjects may not understand statements, or select statements that do not necessarily best reflect their sensory experience: a situation described in Bianchi et al. ${ }^{19}$ The use of descriptors volunteered by subjects in their own words is relatively uncommon but may provide a more sensitive or accurate reflection of the sensory experience of the subject. Compared to endorsed language, volunteered descriptors of breathlessness allow a more accurate identification of people with $\mathrm{COPD}^{21}$ and have stronger association with measures of respiratory impairment. ${ }^{14}$

The aim of this study was to determine whether descriptors of breathlessness volunteered by participants in their own words and selected from a list of descriptors differed following an 8 week CPRP, and whether changes in sensory quality of breathlessness would be reflected in responses to pulmonary rehabilitation. 


\section{Methods}

\section{Study Design}

This study used a pre-post test design to explore whether the language used to describe the sensation of breathlessness changed after completion of a CPRP. A secondary objective was to determine whether subjects who modified the language they used to describe their sensation of breathlessness differed in their responses to pulmonary rehabilitation.

\section{Study Subjects}

People with breathlessness arising from a variety of underlying chronic conditions referred to the 8 week CPRP at Repatriation General Hospital in Adelaide, South Australia, were provided with information concerning this study. Participants were eligible for inclusion if they met the spirometric criteria for COPD and were able to attend pre and post CPRP assessments. Subjects with severe musculoskeletal or psychiatric conditions, illiteracy, severe short-term memory loss, conditions rendering exercise unsafe, or unstable COPD (a change in symptoms or management over the previous 2 months) were excluded. Ethical approval was granted by the Human Research Ethics Committee of the University of South Australia (protocol 199/05) and the Research and Ethics Committee of the Repatriation General Hospital (protocol 44/05). All participants provided informed written consent.

\section{Assessments}

All participants were scheduled to undertake baseline assessments within the 4 weeks preceding CPRP, with reassessments planned within 6 months of completing rehabilitation. Severity of airways obstruction was assessed by post-bronchodilator pulmonary function tests (flowvolume loops, plethysmography), graded using the Global Initiative for Chronic Obstructive Lung Disease (GOLD) stages. ${ }^{20}$ The diagnosis of COPD was confirmed by a respiratory physician. Arterial blood gas analysis was completed to determine resting state hypoxemia. Exercise capacity was assessed using the 6-min walk test ( 2 walk tests performed on each occasion of assessment, with maximum distance achieved recorded) performed according to the American Thoracic Society guidelines. ${ }^{22}$ Disease-specific health related quality of life was assessed with the St George's Respiratory Questionnaire (SGRQ, scores range from zero to 100 , with higher scores indicating greater impairment). ${ }^{23}$ The BODE index, ${ }^{24}$ a measure of global respiratory impairment, was calculated from body mass index, air-flow obstruction, disability related to dyspnea (modified Medical Research Council dyspnea scale, ${ }^{25}$ and 6-min walk distance (6MWD). A one unit change in the BODE index is regarded as clinically important. ${ }^{26}$

The language of breathlessness was assessed using a structured interview. ${ }^{14,21}$ This protocol required subjects first to describe their sensation of breathlessness in their own words (volunteered language likely to include physical and affective descriptors) and then to select from a list of breathlessness statements ${ }^{16}$ (endorsed language included only physical sensations). Subjects volunteered terms to describe their sensation of breathlessness in reply to the standard question, "Which words would you use to describe your breathing when it is uncomfortable?" Subjects volunteered as many or as few words as they needed to describe their sensation of breathlessness, without further prompting, and all responses were transcribed verbatim by the interviewer. The interviewer then showed the subject a list of 15 descriptor phrases ${ }^{16}$ and asked the subject to select up to 3 statements that best described the sensation when breathing was uncomfortable. Care was taken to limit adjectives during the explanation and only the terms "breathlessness" and "when breathing is uncomfortable" were used. Severity of dyspnea was assessed at rest using a $10 \mathrm{~cm}$ visual analog scale for breathlessness intensity.

The 8 week CPRP followed the recommendations in the COPD-X Plan 2006. ${ }^{27}$ Each week, participants complete 2 supervised exercise sessions (circuit training; only one supervised session in week 8) at Repatriation General Hospital, supplemented by a daily prescribed exercise regimen at home and a 2-hour education session. The goal of these education sessions was to provide patients with the information necessary to improve their level of understanding, functioning, self-management capacity, and quality of life. The total number of face to face sessions for the CPRP was 31 (16 education sessions and 15 exercise sessions). Currently there is no universally accepted criterion for attendance or definition for failure to complete CPRP. ${ }^{28}$ With per protocol approaches, where an a priori attendance criterion has been specified, data have been excluded from analysis where participants have attended less than $67-100 \%$ of scheduled sessions. ${ }^{28,29,30}$ Conversely, where no a priori attendance criterion has been specified or intention to treat approaches are used, all data, regardless of attendance, are included in analysis, with "completion" defined as having pre and post data available. For example, Waterhouse et $\mathrm{al}^{31}$ conducted a randomized controlled trial of hospital versus community based CPRP. Using an intention to treat approach, participants were included irrespective of attendance rates, as denoted in the ranges reported for each of the interventions (hospital based mean \pm SD attendance $64.6 \pm 36.4 \%$ (range 0 to $100 \%$ ), community based mean $\pm \mathrm{SD}$ attendance $62.5 \pm 37.3 \%$ (range $0-100 \%)^{31}$ 


\section{Data Management}

Data for each outcome measure were collated for each participant, irrespective of frequency of attendance within the CPRP, for whom assessment data were available before and within 6 months of completing the CPRP. Multiple imputation was used to estimate missing values for a single 6-min walk test result for 8 subjects (SOLAS 3.2, Statistical Solutions, Cork, Ireland). Data for volunteered and endorsed descriptors of breathlessness were treated separately, despite a number of similarities in descriptors. Volunteered and endorsed descriptors were allocated to groups of sensory qualities based on those reported by Banzett et al ${ }^{13}$ : air hunger, suffocating, work/effort, tight/ constricted. These categories were derived from the most stable clusters or components reported in previous studies, ${ }^{13,14}$ with the air hunger and suffocating categories combined, as suggested by analysis in Banzett et al ${ }^{13}$ and Parshall. ${ }^{32}$ Where descriptors were unable to be categorized according to previous studies (affective and emotional responses), 3 new categories were created (eg, frightening/ awful/worried, uncomfortable/annoying, and depressed/ regret/helpless). ${ }^{14}$ After allocation there were 6 categories for volunteered language and 4 categories for endorsed language. Rather than analyze the frequency of descriptors within each sensory category as a continuous variable (frequency), data were treated as binary (participants volunteered/endorsed or did not volunteer/endorse). This accounted for all participants in all volunteered and endorsed sensory categories.

\section{Statistical Analysis}

The primary outcome in this study was the language used to describe the sensation of breathlessness (volunteered or endorsed). To date, prospective sample estimates have been unable to be calculated, based on the lack of normative/variance data for language of breathlessness. Therefore, a prospective sample estimate was calculated using increases in the 6MWD as a proxy for improvement. Using the within group data for changes in the 6MWD following CPRP from the meta-analysis by Lacasse et $\mathrm{al}^{2}$ (mean \pm SD improvement $46 \pm 96 \mathrm{~m}$ ), to confidently accept a finding of no significant difference $(\beta=0.2$, power $=80 \%$ ), with a significance level (alpha) of .05 and variance in the 6MWD of $96 \mathrm{~m}$, a sample of 34 participants was required.

The primary analysis concerned whether a significant proportion of subjects changed descriptors (volunteered or endorsed) between baseline and post-CPRP. Potentially, subjects could offer a descriptor before but not after intervention (yes-no), or offer a descriptor after intervention but not before (no-yes), or consistently offer (yes-yes) or not offer a descriptor (no-no) before and after intervention.
The McNemar test for proportional differences accounts for these 4 possibilities and was applied using statistics software (Statistica 8, StatSoft, Tulsa, Oklahoma) with odds ratios and 95\% confidence intervals calculated $(P<.05$ to be regarded as significant). Differences in responsiveness outcomes (6MWD and SGRQ) between subjects who changed descriptors after rehabilitation (yes-no or no-yes) and where no change occurred (yes-yes or no-no) was explored using random effects mixed modeling. ${ }^{33}$ For each sensory category, where an overall significant group or time effect was present, post-hoc $t$ tests with Bonferroni adjustments were undertaken to clarify which group(s) demonstrated significant change.

\section{Results}

Of the 107 participants screened at baseline, 94 participants met the spirometric criterion for COPD, with severity ranging from stage 1 (mild) to stage 4 (very severe), ${ }^{20}$ with 62 participants attending both pre and post CPRP assessments (27 declining reassessment, 4 deceased, and one reassessment completed 12 months after CPRP). Of these, 4 participants did not complete the structured interview for the language of breathlessness on one of the occasions and were excluded from further analysis. Complete data sets (pre and post rehabilitation) were available for 58 participants. When baseline data were compared between groups of participants meeting the criteria for COPD who completed pre and post CPRP assessments $(n=58)$ versus participants who were excluded from analysis $(n=36$ declined reassessment, deceased, no language of breathlessness data on one occasion of assessment, or reassessment outside 6 months after CPRP), excluded participants did not differ in terms of severity of airways obstruction (pulmonary function tests), respiratory related impairment (modified Medical Research Council dyspnea scale), or body mass index, but had significantly lower height $(P=.001)$ and weight $(P=.02)$, functional exercise capacity (6MWD $P=.04)$, lower health related quality of life (SGRQ total score $P=.03$ ), and less attendance at the scheduled CPRP sessions $(P<.001)$ (Table 1).

Follow-up assessments were completed on average 4 months after the final day of the CPRP (mean reassessment day post CPRP $120 \pm 60 \mathrm{~d}$ [Figure]). At follow-up, compared to pre-CPRP assessments, there were statistically significant improvements in 6MWD $(410 \pm 119 \mathrm{~m}$ vs $384 \pm 109 \mathrm{~m}$, mean change $27 \mathrm{~m}, P<.001$, effect size 0.23 ), and BODE index ( $3 \pm 2$ vs $2 \pm 2, P=.003$, effect size -0.50$)$. There were no statistically significant changes in modified Medical Research Council dyspnea score ( $2 \pm 1$ on both occasions) or SGRQ (total) (pre $47 \pm 16$ vs post $45 \pm 18$, mean change -2 points, $P=.09$, effect size -0.12 ). 
Table 1. Summary of Participant Baseline Characteristics for Included and Excluded COPD Participants

\begin{tabular}{|c|c|c|}
\hline & $\begin{array}{l}\text { Complete } \\
\text { Data Sets } \\
\text { (Included) }\end{array}$ & $\begin{array}{c}\text { Incomplete } \\
\text { Data Sets } \\
\text { (Excluded) }\end{array}$ \\
\hline Sample size, no. & 58 & 36 \\
\hline Male/female, no. & $36 / 22$ & $11 / 25$ \\
\hline Age, y & $71 \pm 9$ & $68 \pm 12$ \\
\hline Height, cm & $168 \pm 9$ & $160 \pm 11^{*}$ \\
\hline Weight, kg & $77 \pm 18$ & $68 \pm 18 \dagger$ \\
\hline Body mass index, $\mathrm{kg} / \mathrm{m}^{2}$ & $27 \pm 5$ & $27 \pm 7$ \\
\hline English as first language, no. (\%) & $54(93)$ & $34(94)$ \\
\hline \multicolumn{3}{|l|}{ Comorbid Conditions, no. (\%) } \\
\hline Cardiovascular disease & $32(55)$ & $15(42)$ \\
\hline Sleep disorder & $8(14)$ & $8(22)$ \\
\hline Osteoporosis & $7(12)$ & $9(25)$ \\
\hline Diabetes & $3(5)$ & $6(17)$ \\
\hline Anxiety/panic disorder & $10(10)$ & $9(25)$ \\
\hline Depression & $9(9)$ & $11(31)$ \\
\hline mMRC dyspnea score & $2 \pm 1$ & $2 \pm 1$ \\
\hline \multicolumn{3}{|l|}{ mMRC dyspnea score, no. (\%) } \\
\hline 0 & $4(7)$ & $2(6)$ \\
\hline 1 & $25(43)$ & $11(31)$ \\
\hline 2 & $7(12)$ & $3(8)$ \\
\hline 3 & $16(28)$ & $13(36)$ \\
\hline 4 & $6(10)$ & $7(19)$ \\
\hline SGRQ total & $48 \pm 15$ & $58 \pm 21$ \\
\hline 6MWD, m & $375 \pm 102$ & $336 \pm 110$ \\
\hline Rehabilitation attendance, $\%$ & $81 \pm 21$ & $48 \pm 33 \ddagger$ \\
\hline $\mathrm{P}_{\mathrm{aCO}_{2}}, \mathrm{~mm} \mathrm{Hg}$ & $40 \pm 5$ & $41 \pm 5$ \\
\hline $\mathrm{P}_{\mathrm{aO}_{2}}, \mathrm{~mm} \mathrm{Hg}$ & $73 \pm 9$ & $74 \pm 8$ \\
\hline $\mathrm{FEV}_{1}, \%$ predicted & $58 \pm 24$ & $51 \pm 19$ \\
\hline FVC, $\%$ predicted & $85 \pm 18$ & $79 \pm 16$ \\
\hline $\mathrm{FEV}_{1} / \mathrm{FVC}$ & $0.46 \pm 0.15$ & $0.47 \pm 0.16$ \\
\hline Residual volume, $\%$ of total lung capacity & $50 \pm 11$ & $52 \pm 10$ \\
\hline \multicolumn{3}{|l|}{$\begin{array}{l} \pm \text { Values are mean } \pm \mathrm{SD} . \\
\begin{array}{l}* \\
\dagger P=.001 .\end{array} \\
\ddagger P=.03 . \\
¥ P<.001 . \\
\text { mMRC }=\text { Modified Medical Research Council dyspnea scale } \\
\text { SGRQ }=\text { St George's Respiratory Questionnaire } \\
\text { 6MWD }=6 \text {-min walk distance }\end{array}$} \\
\hline
\end{tabular}

\section{Changes in Language of Breathlessness}

The number of subjects who changed volunteered descriptors ranged between 8 (14\% yes-no) and 21 (36\% no-yes) (Table 2). After CPRP there was a significant reduction in the number of subjects who had volunteered descriptors denoting air hunger and depressed/regret/ helpless before CPRP (change in air hunger, $n=16,28 \%$, $P=.03)$, depressed/regret/helpless, $n=14,24 \%, P=.04$, see Table 2). The number of subjects who modified their endorsed descriptor selection ranged between 16 (28\% yes to no) and 22 (38\% no to yes) (see Table 2). The proportion of people changing selection of endorsed statements
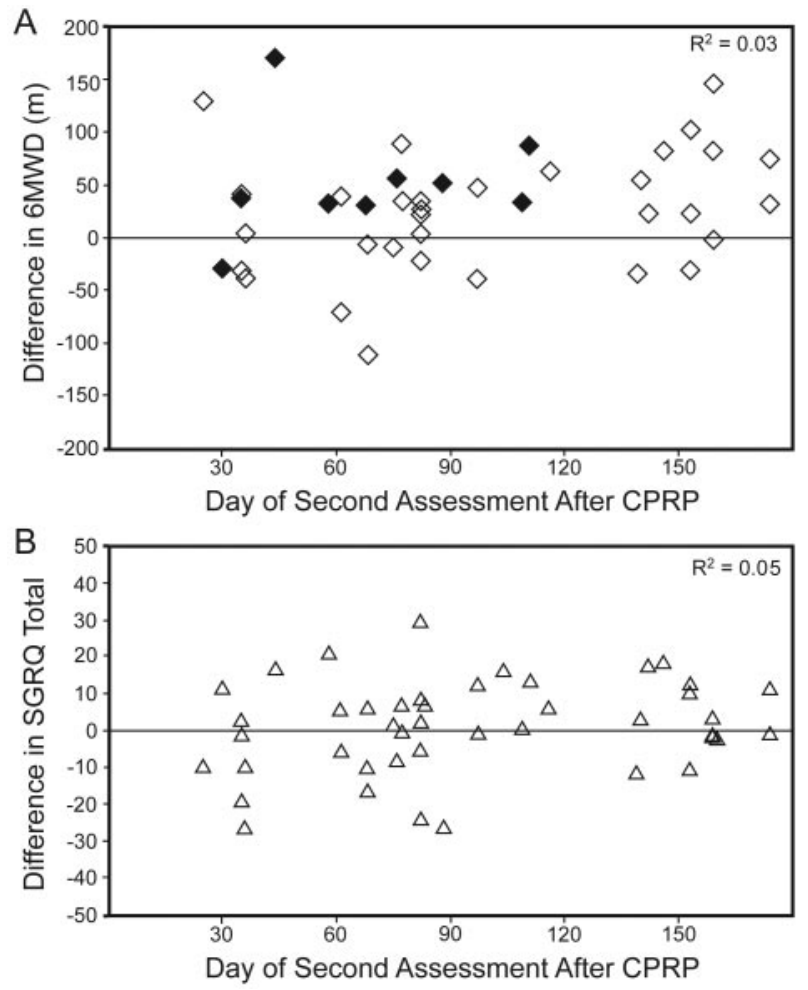

Figure. A: Relationship between change in 6-min walk distance (6MWD) distance $(\mathrm{m})$ and day of reassessment after comprehensive pulmonary rehabilitation program (CPRP) $(n=58)$. Subjects reducing use of descriptors of air hunger (yes before CPRP and no after CPRP) identified in black. B: Relationship between change in Saint George's Respiratory Questionnaire (SGRQ) total points and day of reassessment after CPRP $(n=58)$.

after CPRP was not significant for any of the endorsed sensory categories.

\section{Language of Breathlessness and Responsiveness to Pulmonary Rehabilitation}

Table 3 shows the volunteered descriptors. There were significant differences in 6MWD between subjects who modified their language of breathlessness and those who did not (air hunger $P=.006$, depressed/regret/helpless $P=.01)$. Subjects volunteering descriptors of air hunger before rehabilitation, but not after, demonstrated greater improvements in the 6MWD. In the depressed/regret/ helpless category, subjects who did not change descriptors between occasions of assessment also demonstrated significant improvement in the 6MWD. There were no significant differences in language categories for changes in the SGRQ score between subjects.

Table 4 shows the endorsed descriptors. There were no significant differences for changes in the 6MWD or SGRQ between subjects who did or did not alter their selection of descriptors. 
Table 2. Number of Subjects Modifying or Not Modifying Descriptors in Each Language Category (Volunteered and Endorsed) Before and After Completion of the Comprehensive Pulmonary Rehabilitation Program*

\begin{tabular}{|c|c|c|c|c|c|c|c|c|}
\hline & & & \multicolumn{3}{|c|}{ After CPRP } & \multirow{2}{*}{$P \dagger$} & \multirow{2}{*}{$\begin{array}{l}\text { Odds } \\
\text { Ratio }\end{array}$} & \multirow{2}{*}{$95 \% \mathrm{CI}$} \\
\hline & & & No & Yes & Total & & & \\
\hline \multicolumn{9}{|l|}{ Volunteered Language } \\
\hline \multirow[t]{3}{*}{ Air hunger } & Before & No & 20 & 5 & 25 & .03 & & \\
\hline & CPRP & Yes & 16 & 17 & 33 & & 0.31 & \\
\hline & & Total & 36 & 22 & 58 & & & $0.09-0.89$ \\
\hline \multirow[t]{3}{*}{ Work } & Before & No & 42 & 3 & 45 & .22 & & \\
\hline & CPRP & Yes & 8 & 5 & 13 & & 0.37 & \\
\hline & & Total & 50 & 8 & 58 & & & $0.06-1.56$ \\
\hline \multirow[t]{3}{*}{ Tight } & Before & No & 47 & 2 & 49 & .28 & & \\
\hline & CPRP & Yes & 6 & 3 & 9 & & 0.33 & \\
\hline & & Total & 53 & 5 & 58 & & & $0.03-1.86$ \\
\hline \multirow[t]{3}{*}{ Frightening, awful, worried } & Before & No & 21 & 9 & 30 & .82 & & \\
\hline & CPRP & Yes & 11 & 17 & 28 & & 0.81 & \\
\hline & & Total & 32 & 26 & 58 & & & $0.29-2.17$ \\
\hline \multirow[t]{3}{*}{ Uncomfortable, annoying } & Before & No & 20 & 10 & 30 & $>.99$ & & \\
\hline & CPRP & Yes & 11 & 17 & 28 & & 0.90 & \\
\hline & & Total & 31 & 27 & 58 & & & $0.34-2.35$ \\
\hline \multirow[t]{3}{*}{ Depressed, regret, helpless } & Before & No & 35 & 5 & 40 & .04 & & \\
\hline & CPRP & Yes & 14 & 4 & 18 & & 0.36 & \\
\hline & & Total & 49 & 9 & 58 & & & $0.10-1.05$ \\
\hline \multicolumn{9}{|l|}{ Endorsed Language } \\
\hline \multirow[t]{3}{*}{ Air hunger } & Before & No & 3 & 10 & 13 & $>.99$ & & \\
\hline & CPRP & Yes & 10 & 35 & 45 & & 1.00 & \\
\hline & & Total & 13 & 45 & 58 & & & $0.37-2.67$ \\
\hline \multirow[t]{3}{*}{ Work } & Before & No & 21 & 9 & 30 & .66 & & \\
\hline & CPRP & Yes & 12 & 16 & 28 & & 0.75 & \\
\hline & & Total & 33 & 25 & 58 & & & $0.28-1.94$ \\
\hline \multirow[t]{3}{*}{ Tight } & Before & No & 28 & 7 & 35 & .26 & & \\
\hline & CPRP & Yes & 13 & 10 & 23 & & 0.54 & \\
\hline & & Total & 41 & 17 & 58 & & & $0.18-1.45$ \\
\hline \multirow[t]{3}{*}{ Unnamed } & Before & No & 11 & 9 & 20 & .80 & & \\
\hline & CPRP & Yes & 7 & 31 & 38 & & 1.28 & \\
\hline & & Total & 18 & 40 & 58 & & & $0.43-4.06$ \\
\hline $\begin{array}{l}\text { * Example: For the air hunger category, } \\
\text { descriptor before but did so after CPRP, } 2 \\
\text { of people changing from yes to no or no } \\
\dagger P \text { via McNemar test. }\end{array}$ & $\begin{array}{l}\text { olunteere } \\
\text { id not vol } \\
\text { pared to } 1\end{array}$ & $\begin{array}{l}\text { riptor bet } \\
\text { descript } \\
\text { changing }\end{array}$ & $\begin{array}{c}\text { nprel } \\
\text { after }\end{array}$ & nonar & $\begin{array}{l}\text { ion Pro } \\
\text { efore a }\end{array}$ & $\begin{array}{l}\text { P) but } n \\
\text { RP. The }\end{array}$ & $\begin{array}{l}5 \text { peop } \\
\text { ificant }\end{array}$ & $\begin{array}{l}\text { use this } \\
\text { in the number }\end{array}$ \\
\hline
\end{tabular}

\section{Discussion}

In this cohort of people with moderate to severe COPD (\% predicted $\mathrm{FEV}_{1} 58 \pm 24 \%$, dyspnea score $2 \pm 1$ ), without significant resting hypoxemia or hypercapnia, approximately a third modified the language used to describe the sensation of breathlessness between the 2 occasions of assessment (before and after completion of CPRP). A significant proportion of participants modified their language in 2 volunteered categories (air hunger and depressed/ regret/helpless), with significant differences for improvements in the 6MWD evident between subjects who reduced their use of descriptors for air hunger or depressed/ regret/helpless (yes-no) or who did not change (no-no or yes-yes), compared to subjects who volunteered these descriptors on the second occasion of assessment but not before CPRP (no-yes) (air hunger, $P=.006$; depressed/ regret/helpless, $P=.01$ ). Selection of breathlessness descriptors (endorsed) proved relatively insensitive to change between the 2 occasions of assessment.

Conventionally, responsiveness to pulmonary rehabilitation has been defined as a minimum clinically important difference of $54 \mathrm{~m}(95 \% \mathrm{CI} 37-71 \mathrm{~m})$ in the $6 \mathrm{MWD}^{34}$ and/or a change of 4 units of the SGRQ. ${ }^{35}$ While the minimum clinically important difference for the SGRQ is widely accepted, the threshold value for the $6 \mathrm{MWD}$ is a 
Table 3. Volunteered Descriptors: Differences for Primary Measures of Responsiveness to Pulmonary Rehabilitation Between Subjects Who Changed Descriptors of Breathlessness Before and After Pulmonary Rehabilitation (Yes to No or No to Yes), Compared to Those Who Did Not (Yes to Yes or No to No)

\begin{tabular}{|c|c|c|c|c|c|c|c|c|c|}
\hline \multirow[t]{2}{*}{$\begin{array}{l}\text { Language } \\
\text { Category }\end{array}$} & \multirow[t]{2}{*}{ Groups } & \multicolumn{2}{|c|}{$\begin{array}{l}\text { 6-Min Walk Test, } \\
\text { Mean } \pm \text { SE m } \\
(95 \% \mathrm{CI})\end{array}$} & \multirow[t]{2}{*}{$\begin{array}{l}\text { Effect } \\
\text { Size }\end{array}$} & \multirow{2}{*}{$\begin{array}{c}\text { Group/Time } \\
\text { Interaction } P \\
\text { (where significant } \\
\text { Bonferroni corrected) }\end{array}$} & \multicolumn{2}{|c|}{$\begin{array}{l}\text { St George's Respiratory } \\
\text { Questionnaire, } \\
\text { Mean } \pm \text { SE } \\
\text { total score }(95 \% \mathrm{CI})\end{array}$} & \multirow[t]{2}{*}{$\begin{array}{l}\text { Effect } \\
\text { Size }\end{array}$} & \multirow{2}{*}{$\begin{array}{c}\text { Group/Time } \\
\text { Interaction } P \\
\text { (where significant } \\
\text { Bonferroni corrected) }\end{array}$} \\
\hline & & Pre-CPRP & Post-CPRP & & & Pre-CPRP & Post-CPRP & & \\
\hline \multirow[t]{3}{*}{ Air hunger } & Yes/no & $\begin{array}{c}424 \pm 28 \\
(368-480)\end{array}$ & $\begin{array}{c}470 \pm 28 \\
(413-526)\end{array}$ & 0.35 & \multirow{3}{*}{$\begin{array}{c}.01 \\
\text { Mean } \uparrow 46 \mathrm{~m} \\
.86 \\
\text { Mean } \downarrow 29 \mathrm{~m} \\
.02 \\
\text { Mean } \uparrow 26 \mathrm{~m}\end{array}$} & $\begin{array}{c}43 \pm 5 \\
(33-52)\end{array}$ & $\begin{array}{c}45 \pm 4 \\
(36-54)\end{array}$ & -0.05 & \multirow[t]{3}{*}{.33} \\
\hline & No/yes & $\begin{array}{l}279 \pm 50 \\
(180-378)\end{array}$ & $\begin{array}{l}250 \pm 48 \\
(153-347)\end{array}$ & -0.25 & & $\begin{array}{l}53 \pm 8 \\
(37-70)\end{array}$ & $\begin{array}{l}52 \pm 8 \\
(37-67)\end{array}$ & -0.22 & \\
\hline & No change & $\begin{array}{l}382 \pm 18 \\
(346-418)\end{array}$ & $\begin{array}{l}408 \pm 18 \\
(372-445)\end{array}$ & 0.29 & & $\begin{array}{l}49 \pm 3 \\
(42-55)\end{array}$ & $\begin{array}{l}43 \pm 3 \\
(36-49)\end{array}$ & -0.18 & \\
\hline \multirow[t]{3}{*}{ Work } & Yes /no & $\begin{array}{c}418 \pm 42 \\
(334-502)\end{array}$ & $\begin{array}{l}465 \pm 41 \\
(382-547)\end{array}$ & 0.66 & & $\begin{array}{c}45 \pm 8 \\
(29-61)\end{array}$ & $\begin{array}{l}40 \pm 6 \\
(28-52)\end{array}$ & -0.18 & \multirow[t]{3}{*}{.08} \\
\hline & No/yes & $\begin{array}{l}409 \pm 67 \\
(275-543)\end{array}$ & $\begin{array}{l}448 \pm 67 \\
(314-582)\end{array}$ & 0.27 & & $\begin{array}{l}66 \pm 12 \\
(42-90)\end{array}$ & $\begin{array}{c}18 \pm 17 \\
\text { (-16 to } 52)\end{array}$ & -0.03 & \\
\hline & No change & $\begin{array}{c}375 \pm 18 \\
(340-410)\end{array}$ & $\begin{array}{l}398 \pm 18 \\
(363-433)\end{array}$ & 0.20 & & $\begin{array}{c}47 \pm 3 \\
(41-53)\end{array}$ & $\begin{array}{c}46 \pm 3 \\
(40-51)\end{array}$ & 0.06 & \\
\hline \multirow[t]{3}{*}{ Tight } & Yes /no & $\begin{array}{l}445 \pm 49 \\
(347-542)\end{array}$ & $\begin{array}{l}414 \pm 48 \\
(318-509)\end{array}$ & -0.06 & \multirow[t]{3}{*}{.48} & $\begin{array}{c}53 \pm 8 \\
(37-69)\end{array}$ & $\begin{array}{l}53 \pm 8 \\
(37-69)\end{array}$ & -0.05 & \multirow[t]{3}{*}{.34} \\
\hline & No/yes & $\begin{array}{l}450 \pm 83 \\
(284-615)\end{array}$ & $\begin{array}{l}487 \pm 83 \\
(321-652)\end{array}$ & 0.64 & & $\begin{array}{l}58 \pm 12 \\
(33-82)\end{array}$ & ND & ND & \\
\hline & No change & $\begin{array}{c}374 \pm 17 \\
(340-408)\end{array}$ & $\begin{array}{l}407 \pm 17 \\
(373-441)\end{array}$ & 0.31 & & $\begin{array}{c}46 \pm 3 \\
(40-51)\end{array}$ & $\begin{array}{c}43 \pm 3 \\
(38-49)\end{array}$ & -0.05 & \\
\hline \multirow[t]{3}{*}{$\begin{array}{l}\text { Frightening, awful, } \\
\quad \text { worried }\end{array}$} & Yes /no & $\begin{array}{c}329 \pm 36 \\
(257-402)\end{array}$ & $\begin{array}{c}325 \pm 36 \\
(254-397)\end{array}$ & -0.01 & \multirow[t]{3}{*}{.19} & $\begin{array}{c}52 \pm 6 \\
(40-64)\end{array}$ & $\begin{array}{c}48 \pm 6 \\
(36-59)\end{array}$ & -0.34 & \multirow[t]{3}{*}{.85} \\
\hline & No/yes & $\begin{array}{l}428 \pm 40 \\
(348-507)\end{array}$ & $\begin{array}{l}465 \pm 40 \\
(385-545)\end{array}$ & 0.42 & & $\begin{array}{c}36 \pm 7 \\
(23-49)\end{array}$ & $\begin{array}{c}37 \pm 6 \\
(24-49)\end{array}$ & -0.07 & \\
\hline & No change & $\begin{array}{c}389 \pm 18 \\
(352-426)\end{array}$ & $\begin{array}{l}422 \pm 19 \\
(385-459)\end{array}$ & 0.28 & & $\begin{array}{c}48 \pm 3 \\
(42-55)\end{array}$ & $\begin{array}{c}45 \pm 3 \\
(39-51)\end{array}$ & -0.16 & \\
\hline \multirow[t]{3}{*}{$\begin{array}{l}\text { Uncomfortable, } \\
\text { annoying }\end{array}$} & Yes /no & $\begin{array}{c}359 \pm 36 \\
(288-431)\end{array}$ & $\begin{array}{c}388 \pm 36 \\
(317-459)\end{array}$ & 0.32 & \multirow[t]{3}{*}{.32} & $\begin{array}{c}49 \pm 6 \\
(36-61)\end{array}$ & $\begin{array}{l}42 \pm 6 \\
(30-54)\end{array}$ & 0.00 & \multirow[t]{3}{*}{.45} \\
\hline & No/yes & $\begin{array}{c}435 \pm 38 \\
(360-510)\end{array}$ & $\begin{array}{l}436 \pm 37 \\
(362-510)\end{array}$ & 0.03 & & $\begin{array}{c}56 \pm 8 \\
(41-71)\end{array}$ & $\begin{array}{c}46 \pm 6 \\
(34-58)\end{array}$ & -0.21 & \\
\hline & No change & $\begin{array}{c}377 \pm 20 \\
(337-417)\end{array}$ & $\begin{array}{l}410 \pm 20 \\
(370-450)\end{array}$ & 0.25 & & $\begin{array}{l}45 \pm 3 \\
(39-52)\end{array}$ & $\begin{array}{c}45 \pm 3 \\
(38-51)\end{array}$ & -0.18 & \\
\hline \multirow[t]{3}{*}{$\begin{array}{l}\text { Depressed, regret, } \\
\text { helpless }\end{array}$} & Yes /no & $\begin{array}{c}440 \pm 29 \\
(383-499)\end{array}$ & $\begin{array}{l}463 \pm 30 \\
(403-523)\end{array}$ & 0.16 & \multirow{3}{*}{$\begin{array}{c}.49 \\
\text { Mean } \uparrow 23 \mathrm{~m} \\
>.99 \\
\text { Mean } \downarrow 7 \mathrm{~m} \\
.004 \\
\text { Mean } \uparrow 33 \mathrm{~m}\end{array}$} & $\begin{array}{c}54 \pm 5 \\
(45-64)\end{array}$ & $\begin{array}{l}47 \pm 5 \\
(37-57)\end{array}$ & -0.32 & \multirow[t]{3}{*}{.61} \\
\hline & No/yes & $\begin{array}{c}285 \pm 51 \\
(184-387)\end{array}$ & $\begin{array}{c}278 \pm 49 \\
(180-377)\end{array}$ & -0.03 & & $\begin{array}{l}66 \pm 14 \\
(38-94)\end{array}$ & $\begin{array}{c}63 \pm 9 \\
(44-82)\end{array}$ & -0.06 & \\
\hline & No change & $\begin{array}{c}376 \pm 18 \\
(339-412)\end{array}$ & $\begin{array}{l}409 \pm 18 \\
(372-445)\end{array}$ & 0.30 & & $\begin{array}{c}43 \pm 3 \\
(37-49)\end{array}$ & $\begin{array}{c}42 \pm 3 \\
(36-47)\end{array}$ & -0.06 & \\
\hline
\end{tabular}

topic of debate. ${ }^{36,37}$ The most recent estimates of the minimum clinically important difference for the 6MWD for people with COPD completing pulmonary rehabilitation fall well below $54 \mathrm{~m}$, with Puhan et $\mathrm{al}^{38}$ determining $35 \mathrm{~m}$ (95\% CI 30-42 m) and Holland et al, ${ }^{39} 25 \mathrm{~m}$ (95\% CI 20-61 m). While the mean improvements for the 6MWD (27 $\mathrm{m}$, effect size 0.23$)$ and SGRQ (total) $(-2.0$, effect size -0.12 ) were less than those reported as the common effect between CPRP and usual care by Lacasse et $\mathrm{al}^{2}$ (6MWD 48 m, 95\% CI 32-65 m) and SGRQ (total) -6.11
(95\% CI -8.98 to -3.24 ), our results fall within the effect size $(95 \% \mathrm{CI})$ for the CPRP intervention groups (withingroup pre-post) of studies with similar CPRP duration, participant severity and 4-6 months follow-up periods included within the meta-analysis by Lacasse et $\mathrm{al}^{2}$ (6MWD pooled effect size $0.36,95 \% \mathrm{CI}=0.10-0.63)^{40-45}$ and SGRQ (total score) pooled effect size -0.46 (95\% CI -0.88 to -0.03$)$. $^{41,44-46}$

There is a paucity of longitudinal data exploring the natural progression or the impact of pharmacologic or non- 
Table 4. Endorsed Descriptors: Differences for Primary Measures of Responsiveness to Pulmonary Rehabilitation Between Subjects Who Changed Descriptors of Breathlessness Before and After Pulmonary Rehabilitation (Yes to No or No to Yes), Compared to Those Who Did Not (Yes to Yes or No to No)

\begin{tabular}{|c|c|c|c|c|c|c|c|c|c|}
\hline \multirow{2}{*}{$\begin{array}{l}\text { Language } \\
\text { Category }\end{array}$} & \multirow{2}{*}{ Groups } & \multicolumn{2}{|c|}{$\begin{array}{c}\text { 6-Min Walk Test, } \\
\text { Mean } \pm \text { SE m }(95 \% \text { CI })\end{array}$} & \multirow{2}{*}{$\begin{array}{l}\text { Effect } \\
\text { Size }\end{array}$} & \multirow{2}{*}{$P$} & \multicolumn{2}{|c|}{$\begin{array}{l}\text { St George's Respiratory Questionnaire } \\
\text { Mean } \pm \text { SE total score }(95 \% \text { CI })\end{array}$} & \multirow{2}{*}{$\begin{array}{l}\text { Effect } \\
\text { Size }\end{array}$} & \multirow{2}{*}{$P$} \\
\hline & & Pre-CPRP & Post-CPRP & & & Pre-CPRP & Post-CPRP & & \\
\hline \multirow[t]{3}{*}{ Air hunger } & Yes/no & $392 \pm 39(314-470)$ & $409 \pm 39(330-488)$ & 0.26 & .27 & $48 \pm 6(35-60)$ & $43 \pm 6(30-56)$ & 0.26 & .74 \\
\hline & No/yes & $351 \pm 39(273-429)$ & $352 \pm 39(273-431)$ & 0.01 & & $54 \pm 6(43-66)$ & $49 \pm 6(37-61)$ & 0.13 & \\
\hline & No change & $389 \pm 19(350-426)$ & $424 \pm 19(385-462)$ & 0.28 & & $45 \pm 3(38-51)$ & $43 \pm 3(37-49)$ & 0.12 & \\
\hline \multirow[t]{3}{*}{ Work } & Yes/no & $390 \pm 35(318-461)$ & $409 \pm 36(338-480)$ & 0.16 & .90 & $51 \pm 5(40-62)$ & $47 \pm 5(37-58)$ & 0.06 & .86 \\
\hline & No/yes & $336 \pm 39(258-414)$ & $363 \pm 40(283-442)$ & 0.26 & & $50 \pm 7(35-65)$ & $51 \pm 8(35-67)$ & 0.07 & \\
\hline & No change & $394 \pm 20(354-433)$ & $422 \pm 20(383-462)$ & 0.24 & & $45 \pm 3(39-52)$ & $43 \pm 3(37-49)$ & 0.17 & \\
\hline \multirow[t]{3}{*}{ Tight } & Yes/no & $402 \pm 32(337-468)$ & $444 \pm 33(378-510)$ & 0.57 & .48 & $39 \pm 5(29-50)$ & $37 \pm 5(26-47)$ & 0.00 & .88 \\
\hline & No/yes & $330 \pm 48(234-425)$ & $370 \pm 48(274-465)$ & 0.29 & & $54 \pm 7(40-68)$ & $54 \pm 7(40-68)$ & 0.13 & \\
\hline & No change & $385 \pm 19(347-424)$ & $406 \pm 19(367-444)$ & 0.15 & & $49 \pm 3(42-55)$ & $45 \pm 3(39-51)$ & 0.17 & \\
\hline \multirow[t]{3}{*}{ Unnamed } & Yes/no & $362 \pm 47(267-457)$ & $340 \pm 47(245-435)$ & -0.17 & .07 & $52 \pm 7(38-67)$ & $48 \pm 7(34-63)$ & 0.27 & .65 \\
\hline & No/yes & $433 \pm 41(351-515)$ & $459 \pm 41(377-542)$ & 0.33 & & $47 \pm 6(35-59)$ & $49 \pm 6(36-62)$ & 0.12 & \\
\hline & No change & $377 \pm 18(340-413)$ & $412 \pm 18(376-448)$ & 0.26 & & $46 \pm 3(40-53)$ & $43 \pm 3(37-49)$ & 0.11 & \\
\hline
\end{tabular}

$\mathrm{CPRP}=$ Comprehensive Pulmonary Rehabilitation Program

pharmacologic interventions on the sensory quality of breathlessness. In the current study, as well as previous reports, ${ }^{18,19}$ causality between participation in pulmonary rehabilitation and changes in the sensory quality of breathlessness cannot be confirmed, due to the absence of control data. While von Leupoldt et al ${ }^{18}$ reported significant reductions in the intensity of sensory qualities immediately following participation in a 15 day CPRP, in the current study it is possible that the changes found in descriptors between the 2 occasions of assessment may have been confounded by the duration of time from completion of CPRP and reassessment or changes in clinical state over the duration of the study. The health benefits of pulmonary rehabilitation decay over the subsequent $12-18$ months $^{1}$; however, in this study there was a negligible association between the size of the change in 6MWD $\left(\mathrm{R}^{2}=0.03\right)$ or SGRQ (total) $\left(\mathrm{R}^{2}=0.05\right)$ and time of reassessment after completion of CPRP (see Fig. 1). Where deteriorations occurred in the 6MWD on the second occasion of assessment (volunteered categories: air hunger $29 \mathrm{~m}$, tight $31 \mathrm{~m}$, frightening $4 \mathrm{~m}$; endorsed category: unnamed $22 \mathrm{~m}$ ), these generally exceeded the deterioration estimated as the natural progression of COPD $(12.5 \mathrm{~m} / \mathrm{y}, 95 \%$ CI $8-17 \mathrm{~m} / \mathrm{y}){ }^{47}$ Small increases in $\mathrm{FEV}_{1}(\mathrm{~mL})$ were found for all subgroups on the second occasion of assessment, negating the likelihood of acute clinical deterioration during the study.

Descriptors of work/effort or unsatisfied inspiration/ air hunger are commonly reported by people with COPD on recall and with breathlessness induced by exercise. . $^{7,814,18,19,21,48}$ Unless participants were volunteering or selecting descriptors randomly on both assessment occasions, the descriptors are likely to reflect the individual's current perception of breathlessness. The pattern of descriptor modification in relation to changes in primary outcomes after CPRP varied substantially (see Tables 3 and 4). Sensory qualities of breathlessness are not mutually exclusive; subjects experience a combination of qualities, ${ }^{12,49}$ resulting in large variations among individual sensory quality profiles. In this study, $>70 \%$ of subjects volunteered or endorsed descriptors in 2 or more language categories: single, 2, 3, or 4 language categories: volunteered $29 \%, 39 \%, 24 \%$, and $8 \%$, and endorsed $15 \%, 42 \%$, $43 \%$, and $0 \%$, respectively.

A change in descriptor categories may reflect an improvement (yes-no), which may be associated with improved health outcomes (eg, 6MWD) or a deterioration (no-yes), which may be associated with no or smaller improvements in health outcomes. Where there is no change in descriptor use, the descriptor is either irrelevant to the individual (no-no) or is consistently experienced by the individual (yes-yes), and therefore changes in health outcomes might be expected to fall between the "improvers" and deterioraters."

Theoretically, the greatest increases in 6MWD might be expected in the "yes-no" group, followed by the "no change" group, and then the "no-yes" group. Given the multiplicity of analysis and small sample size, the most plausible finding in this study was for changes in the 6MWD in the volunteered air hunger category (yes-no $46 \mathrm{~m}$, no change $26 \mathrm{~m}$, no-yes $-29 \mathrm{~m}$ ). There were 5 language categories (out of the potential 10) for which the largest increase in the 6MWD occurred in the "no change" group. In 3 of these categories the difference between the "no change" group and the next largest increase in the 6MWD was 
negligible (volunteered: uncomfortable; endorsed: work/ effort and unnamed). The pattern of findings for the remaining 2 categories (volunteered: depressed/regret/helpless; endorsed: air hunger) might be due to chance (small numbers in the yes-no and no-yes categories).

One of the key challenges in studying the effect of interventions on the sensation of breathlessness is the analysis of descriptor data. Previous authors have invited subjects to assess the intensity of all ${ }^{18}$ or select up to $3^{19}$ descriptor statements, prior to pooling descriptors into sensory categories (clusters) and calculating measures of central tendency ${ }^{18}$ or frequency of descriptor selection. ${ }^{19}$ Both approaches quantify sensory quality data and reduce the "noise" in inter-subject variation, but at the expense of identifying individuals' changes in descriptor choice. We included descriptors volunteered and endorsed by subjects, and chose an alternative analysis approach that identified individual changes but created substantial "noise" as a result of the multitude of individual sensory profiles. Regardless of the analysis choice, only the most frequent or dominant sensory profiles are likely to be readily identified.

Repeated exposure to exercise training such as that included within CPRPs leads to improvements in system efficiency (decreased ventilatory effort for same work load) and familiarity (decreased sensitivity) to the sensation of breathlessness. ${ }^{1-7}$ These mechanisms have the potential to alter inputs into the perceptual processes for the sensation of breathlessness. ${ }^{9,49}$ The greatest mean improvements in the 6MWD were for subjects no longer volunteering descriptors of air hunger (increase of $46 \mathrm{~m}$ ) or work/effort (increase of $47 \mathrm{~m}$, see Table 3). It is tempting to speculate that subjects reporting a reduction in sensations of air hunger or work/effort might be those for whom the exercise training resulted in desensitization through improvements in global strength, reducing the work of breathing for a given work rate, or delaying the onset of dynamic hyperinflation during exercise ${ }^{8,12}$; however, specific studies to examine the potential mechanisms are warranted.

The greatest mean deterioration in the 6MWD was for subjects volunteering new descriptors of air hunger (decrease of $29 \mathrm{~m}$, see Table 3). In theory, if sensation drives behavior, these may be the subjects for whom the behavioral consequences of unpleasant sensation make it difficult to improve or maintain health outcomes, especially those relating to exercise. This may provide one explanation for the relatively small overall changes in exercise capacity (6MWD) in this group and recorded in some other studies. ${ }^{37,40-43,45}$ Adjunctive strategies either to reduce the physiological work of breathing during exercise (eg, supported ventilation during exercise, ${ }^{50}$ heliox ${ }^{51}$ ) or to alter cognitive/affective processes underpinning the perception of breathlessness (cognitive behavioral therapy, opioids or other strategies ${ }^{52}$ ) may provide an important therapeutic avenue for such people.

\section{Conclusions}

Subjects reducing their use of descriptors of air hunger, compared to subjects increasing or consistently using these descriptors, had the greatest improvements in the 6MWD after rehabilitation (mean increases of $46 \mathrm{~m}$ ), though these findings - and the underlying mechanisms — need to be confirmed though further studies. Descriptors of breathlessness may provide a means of monitoring change in perceptual process for sensation of breathlessness. Consistent or new use of descriptors reflecting adverse sensory quality or emotional responses to breathlessness may identify people for whom adjunctive strategies could be considered.

\section{ACKNOWLEDGMENTS}

The authors would like to thank the patients and the staff of the Respiratory Function Unit, Repatriation General Hospital, for willingness to participate in this study.

\section{REFERENCES}

1. Ries AL, Bauldoff GS, Carlin BW, Casaburi R, Emery CF, Mahler DA, et al. Joint ACCP/AACVPR Evidence-Based Clinical Practice Guidelines. Pulmonary rehabilitation. Chest 2007;131(5):4S-42S

2. Lacasse Y, Goldstein R, Lasserson TJ, Martin S. Pulmonary rehabilitation for chronic obstructive pulmonary disease. Cochrane Database Syst Rev 2006;(4):CD003793. DOI: 10.1002/14651858. CD003793.pub2.

3. Troosters T, Gosselink R, Janssens W,Decramer M. Exercise training and pulmonary rehabilitation: new insights and remaining challenges. Eur Respir Rev 2010;19(115):24-29.

4. Solanes I, Güell R, Casan P, Sotomayer C, Gonzalas A, Feixas T, et al. Duration of pulmonary rehabilitation to achieve a plateau in quality of life and walk test in COPD. Respir Med 2009;103(5):722-728.

5. Casaburi R, ZuWallack R. Pulmonary rehabilitation for management of chronic obstructive pulmonary disease. N Engl J Med 2009; 360(13):1329-1325.

6. Porszasz J, Emtner M, Goto S, Somfay A, Whipp BJ, Casaburi R. Exercise training decreases ventilatory requirements and exerciseinduced hyperinflation at submaximal intensities in patients with COPD. Chest 2005;128(4):2025-2034.

7. O'Donnell DE, Ora J, Webb K, Laveneziana P, Jensen D. Mechanisms of activity-related dyspnea in pulmonary diseases. Respir Physiol Neurobiol 2009;167(1):116-132.

8. Ora J, Jensen D, O'Donnell DE. Exertional dyspnoea in chronic obstructive pulmonary disease: mechanisms and treatment approaches. Curr Opin Pulm Med 2010;16(2):144-149.

9. Lansing R, Gracely R, Banzett R. The multiple dimensions of dyspnea: Review and hypothesis. Respir Physiol Neurobiol 2009;167(1): 53-60.

10. Von Leupoldt A, Dahme B. Differentiation between the sensory and affective dimension of dyspnea during resistive load breathing in normal subjects. Chest 2005;128(5):3345-3349.

11. Borg G. Perceived exertion as an indicator of somatic stress. Scan J Rehabil Med 1970;2(2):92-98. 


\section{Volunteered Descriptors of Air Hunger}

12. Scano G, Innocenti-Bruni G, Stendardi L. Do obstructive and restrictive diseases share common underlying mechanism of breathlessness? Respir Med 2010;104(7):925-933.

13. Banzett R, Pedersen S, Schwartzstein R, Lansing RW. The affective dimension of laboratory dyspnea: air hunger is more unpleasant than work/effort. Am J Respir Crit Care Med 2008;177(12):1384-1390.

14. Williams MT, Cafarella P, Olds T, Petkov J, Frith P. Affective descriptors of the sensation of breathlessness are more highly associated with severity of impairment than physical descriptors in people with chronic obstructive pulmonary disease. Chest 2010;138(2): 315-322.

15. Simon PM, Schwartzstein RM, Weiss JW, Fenci V, Teghtsoonian N, Weinberger SE. Distinguishable types of dyspnoea in patients with shortness of breath. Am Rev Respir Dis 1990;142(5):1009-1014.

16. Mahler DA, Harver A, Lentine T,Scott JA, Beck K, Schwartstein RM. Descriptors of breathlessness in cardiorespiratory diseases. Am J Respir Crit Care Med 1996;154(5):1357-1363.

17. Yorke J, Moosavi SH, Shuldham C, Jones PW. Quantification of dyspnoea using descriptors: development and initial testing of the Dyspnoea-12. Thorax 2010;65(1):21-26.

18. Von Leupoldt A, Balewski S, Petersen S, Taube K, Schubert-Heukeshoven S, Magnussen H, Dahme B. Verbal descriptors of dyspnea in patients with COPD at different intensity levels of dyspnea. Chest 2007;132(1):141-147.

19. Bianchi R, Gigliotti F, Romagnoli I, Lanini B, Castellanni C, Binazzi $\mathrm{B}$ et al. Impact of a rehabilitation program on dyspnea intensity and quality in patients with chronic obstructive pulmonary disease. Respiration 2011;81(3):186-195.

20. Global Initiative for Chronic Obstructive Lung Disease (GOLD). Global strategy for the diagnosis, management and prevention of COPD. Updated December 2011. http://www.goldcopd.org/guidelines-global-strategy-for-diagnosis-management.html. Accessed June 22, 2012.

21. Williams MT, Cafarella P, Olds T, Petkov J, Frith P. The language of breathlessness differentiates between patients with chronic obstructive pulmonary disease and age-matched adults. Chest 2008; 134(3):489-496.

22. American Thoracic Society Statement. Guidelines for the six minute walk test. Am J Respir Crit Care Med 2002;166(1):111-117.

23. Jones PW, Quirk FH, Baveystock CM, Littlejohns P. A self-complete measure for chronic airflow limitation: the St George's Respiratory Questionnaire. Am Rev Respir Dis 1992;145(6):1321-1327.

24. Celli BR, Cote CG, Marin JM, Casanova C, Montes de Oca M, Mendez RA, et al. The body-mass index, airflow obstruction, dyspnea, and exercise capacity index in chronic obstructive pulmonary disease. N Engl J Med 2004;350(10):1005-1012.

25. Bestall JC, Paul EA, Garrod R, Garnham R, Jones P, Wedzicha J. Usefulness of the Medical Research Council (MRC) dyspnoea scale as a measure of disability in patients with chronic obstructive pulmonary disease. Thorax 1999;54(7):581-586.

26. Cote CG, Celli BR. Pulmonary rehabilitation and the BODE index in COPD. Eur Respir J 2005;26(4):630-636.

27. Abramson MJ, Crockett AJ, Frith PA and McDonald CF. COPDX: an update of guidelines for the management of chronic obstructive pulmonary disease with a review of recent evidence. MJA 2006; 184(7):342-345

28. Keating A, Lee AL, Holland AE. Lack of perceived benefit and inadequate transport influence uptake and completion of pulmonary rehabilitation in people with chronic obstructive pulmonary disease. J Physiother 2011;57(3):183-190.

29. Cockram J, Cecins N, Jenkins S. Maintaining exercise capacity and quality of life following pulmonary rehabilitation. Respirology 2006; 11(1):98-104.
30. Eaton T, Young P, Fergusson W, Moodie L, Zeng I, O'Kane F, et al. Does early pulmonary rehabilitation reduce acute health care utilization in COPD patients admitted with an exacerbation? A randomised controlled trial. Respirology 2009;14(2):230-238.

31. Waterhouse JC, Walters SJ, Oluboyede Y, Lawson RA. A randomized $2 \times 2$ trial of community versus hospital pulmonary rehabilitation for chronic obstructive pulmonary disease followed by telephone or conventional followup. Health Technol Assess 2010;14(6):i-v, viixi, $1-140$

32. Parshall MB. Psychometric characteristics of dyspnea descriptor ratings in emergency department patients with exacerbated chronic obstructive pulmonary disease. Res Nurs Health 2002;25(5):331-344.

33. Hedeker DR, Gibbons RD. Longitudinal data analysis. Hoboken, NJ: Wiley; 2006:47-64

34. Redelmeier DA, Bayoumi AM, Goldstein RS, Guyatt GH. Interpreting small differences in functional status:the six minute walk test in chronic lung disease. Am J Respir Crit Care Med 1997;155(4):12781282.

35. Jones PW. Interpreting thresholds for a clinically significant change in health status in asthma and COPD. Eur Respir J 2002;19(3):398404.

36. Jenkins SC. 6-minute walk test in patients with COPD: clinical applications in pulmonary rehabilitation. Physiother 2007;93(3):175182.

37. De Torres JP, Pinto-Plata V, Ingenito E, Bagley P, Gray A, Berger R, Celli B. Power of outcome measurements to detect clinically significant changes in pulmonary rehabilitation of patients with COPD. Chest 2002;121(4):1092-1098.

38. Puhan MA, Mador MJ, Held U, Goldstein R, Guyatt GH, Schunemann HJ. Interpretation of treatment changes in the 6-minute walk distance in patients with COPD. Eur Respir J 2008;32(3): 637-643.

39. Holland AE, Hill CJ, Rasekaba T, Lee A, Naughton MT, McDonald CF. Updating the minimal important difference for six-minute walk distance in patients with chronic obstructive pulmonary disease. Arch Phys Med Rehabil 2010;91(2):221-225.

40. Behnke M, Taube C, Kirsten D, Lehnigk B, Jorres RA, Magnussen $\mathrm{H}$. Home-based exercise is capable of preserving hospital-based improvements in severe chronic obstructive pulmonary disease. Respir Med 2000;94(12):1184-1191.

41. Ringbaek TJ, Broendum E, Hemmingsen L, Lybek D, Nielsen D, Andersen D, et al. Rehabilitation of patients with chronic obstructive pulmonary disease. Exercise twice a week is not sufficient! Respir Med 2000;94(2):150-154.

42. Cambach W, Chadwick-Straver RVM, Wagenaar RC, van Keimpema AR, Kemper HC. The effects of a community-based pulmonary rehabilitation programme on exercise tolerance and quality of life: a randomized controlled trial. Eur Respir J 1997;10(1):104-113.

43. Simpson K, Killian K, McCartney N, Stubbing DG, Jones NL. Randomised controlled trial of weightlifting exercise in patients with chronic airflow limitation. Thorax 1992;47(2):70-75.

44. Finnerty JP, Keeping I, Bullough I, Jones J. The effectiveness of outpatient pulmonary rehabilitation in chronic lung disease. A randomized controlled trial. Chest 2001;119(6):1705-1710.

45. Boxall AM, Barclay L, Sayers A, Caplan C. Managing chronic obstructive pulmonary disease in the community: a randomized controlled trial of home-based pulmonary rehabilitation for elderly housebound patients. J Cardiopulm Rehabil 2005;25(6):378-385.

46. Wedzicha JA, Bestall KJC, Garrod R, Garnham R, Paul EA, Jones PW. Randomised controlled trial of pulmonary rehabilitation in severe chronic obstructive pulmonary disease patients, stratified by the MRC dyspnoea scale. Eur Respir J 1998;12(2):363-369. 


\section{VolunteEREd Descriptors of Air Hunger}

47. Casanova C, Cote CG, Marin JM, de Torres JP, Aguirre-Jaimie A, Mendez R et al. The 6-min walking distance: long term follow-up of patients with COPD. Eur Respir J 2007;29(3):535-540.

48. Williams MT, Garrard A, Cafarella P, Petkov J, Frith P. Quality of recalled dyspnoea is different from exercise-induced dyspnoea: an experimental study Aust J Physiother 2009;55(3):177-183.

49. O'Donnell DE, Banzett BB, Carrieri-Kohlman V, Casaburi R, Davenport PW, Gandevia SC et al. Pathophysiology of dyspnea in chronic obstructive pulmonary disease. A roundtable. Proc Am Thorac Soc 2007;4(2):145-168
50. Van't H, Kwakkel G, Gosselink R. The acute effects of noninvasive ventilatory support during exercise on exercise endurance and dyspnoea in patients with chronic obstructive pulmonary disease. A systemic review. J Cardiopulm Rehabil 2002;22(4):290-297.

51. Hunt T, Williams MT, Frith P, Schembri P. Heliox, dyspnoea and exercise in chronic obstructive pulmonary disease: a systematic review. Eur Respir Rev 2010;19(115):30-38.

52. Mahler DA, Selecky PA, Harrod CG. The ACCP consensus statement on the management of dyspnoea in patients with advanced lung or heart disease. Chest 2010;137(5):674-691. 